\title{
Groundwater Pollution and Human Health Risks in an Industrialized Region of Southern India: Impacts of the COVID-19 Lockdown and the Monsoon Seasonal Cycles
}

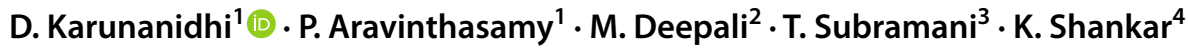

Received: 6 October 2020 / Accepted: 2 December 2020 / Published online: 4 January 2021

(c) The Author(s), under exclusive licence to Springer Science+Business Media, LLC part of Springer Nature 2021

\begin{abstract}
Samples of groundwater were collected during a post-monsoon period (January) and a pre-monsoon period (May) in 2020 from 30 locations in the rapidly developing industrial and residential area of the Coimbatore region in southern India. These sampling periods coincided with times before and during the lockdown in industrial activity and reduced agricultural activity that occurred in the region due to the COVID-19 pandemic. This provided a unique opportunity to evaluate the effects of reduced anthropogenic activity on groundwater quality. Approximately $17 \%$ of the wells affected by high fluoride concentrations in the post-monsoon period returned to levels suitable for human consumption in samples collected in the pre-monsoon period. This was probably due to ion exchange processes, infiltration of rainwater during the seasonal monsoon that diluted concentrations of ions including geogenic fluoride, as well as a reduction in anthropogenic inputs during the lockdown. The total hazard index for fluoride in the post-monsoon samples calculated for children, adult women, and adult men indicated that $73 \%, 60 \%$, and $50 \%$ of the groundwater samples, respectively, had fluoride levels higher than the permissible limit. In this study, nitrate pollution declined by $33.4 \%$ by the pre-monsoon period relative to the post-monsoon period. The chemi$\mathrm{cal}$ facies of groundwater reverted from the $\mathrm{Na}-\mathrm{HCO}_{3}-\mathrm{Cl}$ and $\mathrm{Na}-\mathrm{Cl}$ to the $\mathrm{Ca}-\mathrm{HCO}_{3}$ type in pre-monsoon samples. Various geogenic indicators like molar ratios, inter-ionic relations along with graphical tools demonstrated that plagioclase mineral weathering, carbonate dissolution, reverse ion exchange, and anthropogenic inputs are influencing the groundwater chemistry of this region. These findings were further supported by the saturation index assessed for the post- and pre-monsoon samples. COVID-19 lockdown considerably reduced groundwater pollution by $\mathrm{Na}^{+}, \mathrm{K}^{+}, \mathrm{Cl}^{-}, \mathrm{NO}_{3}^{-}$, and $\mathrm{F}^{-}$ions due to shutdown of industries and reduced agricultural activities. Further groundwater quality improvement during lockdown period there is evidence that the COVID-19 lockdown by increased $\mathrm{HCO}_{3}$ - ion concentration. Overall results illustrate the positive benefits to groundwater quality that could occur as a result of measures to control anthropogenic inputs of pollutants.
\end{abstract}

Groundwater is an indispensable global resource for irrigation and domestic use, as well as industrial activities, particularly for arid and semi-arid areas (Su et al. 2020; Wang

D. Karunanidhi

karunasamygis@gmail.com

1 Department of Civil Engineering, Sri Shakthi Institute of Engineering and Technology (Autonomous), Coimbatore 641062, India

2 Department of Applied Chemistry, Priyadarshini Institute of Engineering and Technology, Nagpur 440019, India

3 Department of Geology, CEG, Anna University, Chennai 600025, India

4 Department of Applied Geology, School of Applied Natural Science, Adama Science and Technology University, P.O. Box 1888, Adama, Ethiopia et al. 2020). Groundwater quality is a significant environmental concern globally and requires monitoring of a large number of physicochemical parameters, including cations and anions (Tiwari et al. 2018). Many countries that depend on groundwater as a renewable resource are concerned with declining water quality and quantity in the aquifer (Qasemi et al. 2019; Mohammadi et al. 2018). Because of the economic and technological constraints within countries with emerging economies, groundwater often is used with little or no treatment. This kind of practice is a human health risk associated with exposures to fluoride, nitrates, and many other pollutants present in groundwater (Aravinthasamy et al. 2020b; Amaral et al. 2018; Ghaderpoori et al. 2018).

The presence of fluoride at high concentrations in drinking water has created serious health risks to human populations in many parts of the globe (Shen and Schafer 
2015). Many developed nations practice water fluoridation at low concentrations to protect dental health (Fallahzadeh et al. 2018; Guissouma et al. 2017). Long-term fluoride exposure can lead to acute fluorosis and this condition affects approximately 200 million people in 28 countries (WHO 2006). Susheela (2002) estimated that approximately 66 million people in 250 districts in India are at risk from endemic fluorosis. We previously conducted studies in southern India that indicated that children are particularly sensitive to the health risks from high intake of fluoride-rich drinking water (Karunanidhi et al. 2019, 2020a, b, c, d). Similar studies have been conducted in other countries around the world, such as the United Arab Emirates (Walia et al. 2017); Iran (Yousefi et al. 2018; Dehbandi et al. 2018), China (Zhang et al. 2017), and Tunisia (Guissouma et al. 2017).

Fluoride levels and speciation in groundwater originating from geogenic sources is typically impacted by the vegetation, salinity, complexing ions, anion exchange, temperature, $\mathrm{pH}$, evapotranspiration, the solubility of various fluoridebearing minerals, and the occurrence of precipitation events (Dehbandi et al. 2018). This investigation focused on evaluating risks from exposure to fluoride from intake and dermal exposure in an industrialized region of India using samples of groundwater collected both before and after a monsoon cycle. Within the highly populated Coimbatore region of southern India, there are many small and large industries and also agricultural activities requiring irrigation. The majority of rainfall occurs during the monsoon season, which typically lasts from early June to late September (Anand and Karunanidhi 2020). Infiltration of this rainwater contributes to recharge of the shallow aquifers in the region. Groundwater levels decline during the post-monsoon period. Samples collected in this study in January 2020 during the post-monsoon period and in May 2020 during the pre-monsoon period coincided with before and during the COVID-19 lockdown period in India, when most industries were not operating. Because discharges and wastes generated by industry play an important role in groundwater contamination, we hypothesized that groundwater contamination in the industrialized Coimbatore region would rapidly decline due to reduced anthropogenic inputs during the lockdown.

The main objectives of the present study were to (1) classify the major anthropogenic sources and geochemical processes governing fluoride contamination during post- and pre-monsoon periods (2) demarcate the fluoride susceptible zones in the region using spatial maps, and (3) evaluate the health risks from exposure to fluoride rich groundwater through ingestion of drinking water and dermal pathways. In the future, we anticipate that these data will contribute to water management decisions and plans for remediation and treatment of polluted groundwater in this region in southern India.

\section{Materials and Methods}

\section{Study Area}

The major urban centers in Tamil Nadu state in southern India are Coimbatore, Chennai, Erode, and Tuticorin. Coimbatore is one of the major industrial centers in this region. The Coimbatore district is comprised of 11 townships, or "taluks." Among these, Sulur taluk, which previously was an agriculture area, experienced rapid industrial development during the past two decades. The major industries functioning within the study area are textiles, spinning mills, and engineering industries. The study area is situated on the eastern side of the Coimbatore district between latitudes $10.86^{\circ} \mathrm{N}$ to $11.21^{\circ} \mathrm{N}$ and longitudes $77.06^{\circ} \mathrm{E}$ to $77.22^{\circ} \mathrm{E}$, covering around $583 \mathrm{~km}^{2}$ area (Fig. 1). The area contains different soil categories, including brown loamy soil, black soil, colluvium, and alluvium. The annual precipitation of the study region is $618 \mathrm{~mm}$ in which major rainfall occurs during the monsoon season (June to December). The mean monthly temperatures vary between 20.6 and $38.4{ }^{\circ} \mathrm{C}$.

The study area overlies a complex geological system, mainly composed of granite, charnockite, fissile hornblende biotite gneiss, and hornblende biotite gneiss (GSI 1995). The weathered crystalline rocks and their fracture zones mark the area as a potential aquifer system (Subramani et al. 2012). The usability of surface water in this region for domestic, industrial, and agricultural purposes is restricted due to high levels of pollution in the Noyyal River and surface waters in the surrounding watershed (Priya et al. 2011). The available groundwater resources occur within semiconfined aquifers. The depth of water level in the shallow aquifers of the study region varies from 1.5 to $12 \mathrm{~m}$ during the post-monsoon period (i.e., January 2020) to 4.2 to $15 \mathrm{~m}$ during the pre-monsoon period (i.e., May 2020). The specific yield of open wells varies from 50 to $300 \mathrm{~L}$ per minute $(\mathrm{lpm})$ for a drawdown of 0.5 to $3.5 \mathrm{~m}$. Transmissivity varies from 1 to $1146 \mathrm{~m}^{2} /$ day, and the storability varies from $9.1 \times 10^{-5}$ to $4.7 \times 10^{-3}$.

\section{Sampling Collection}

Samples of groundwater were obtained from 30 shallow wells with depths between 10 and 15 meters located in the industrial and agricultural regions of Sulur taluk during the post-monsoon season (i.e., January) and the premonsoon season (i.e., May) of 2020. All wells are regularly used for domestic, irrigation and industrial purposes. These sampling events coincided with the pre-lock down and lockdown periods, respectively. Industrial activities 


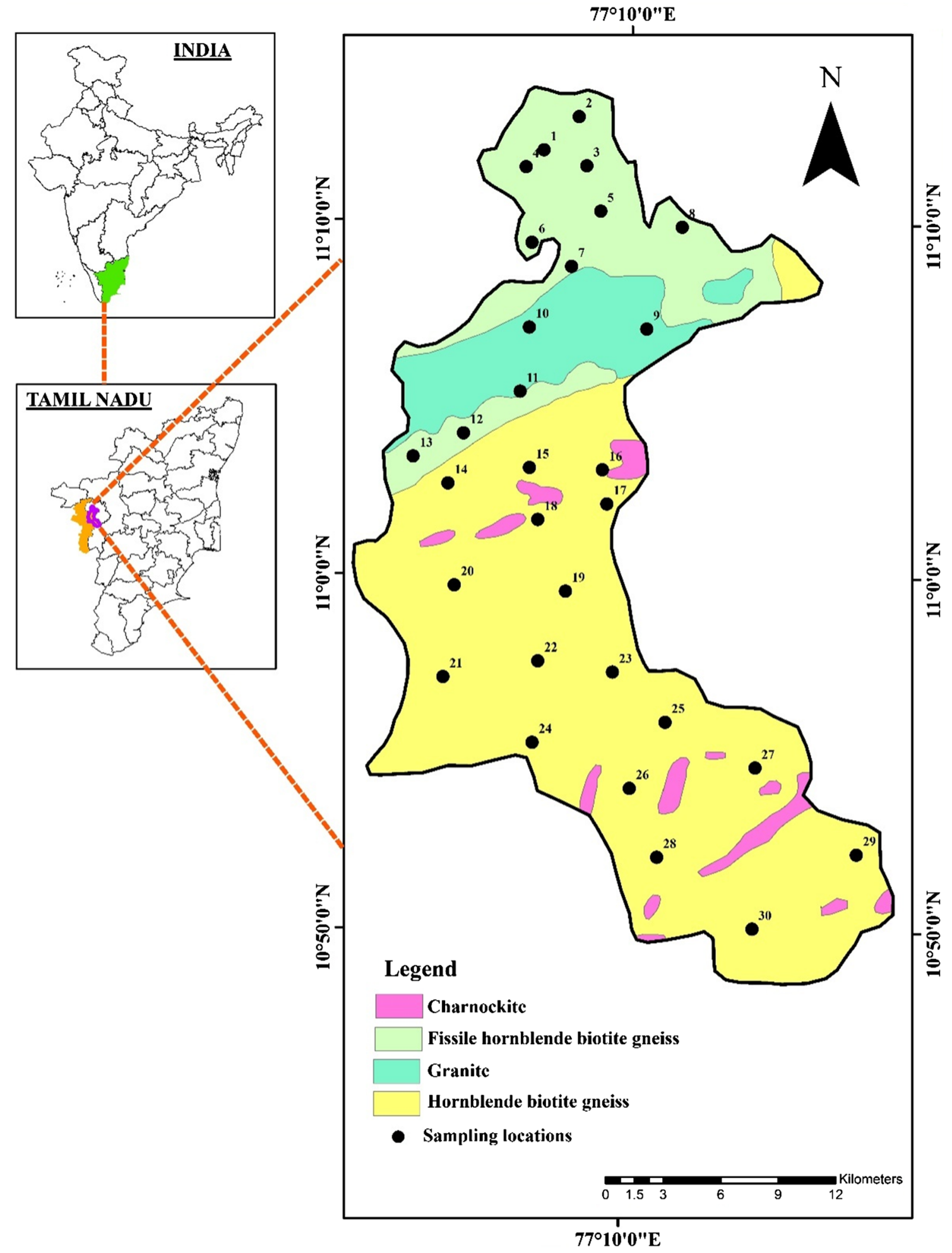

Fig. 1 Groundwater samples collected from different locations and comprising various geological formations in the study region

stopped after the COVID-19 pandemic began to take effect in India, beginning in March 2020. The location details (X, $\mathrm{Y}$, and $\mathrm{Z}$ coordinates) of the sampling wells were documented using a portable global positioning system (GPS).
Pre-washed and pre-labeled one liter polyethylene bottles were used for sample collection. Groundwater was analyzed in the field using a ESICO Model 1160E microprocessor water and soil analysis kit (Esico International, Himachal 
Pradesh, India) for total dissolved solids (TDS) and $\mathrm{pH}$. Samples were then immediately transported to the laboratory for subsequent analysis.

\section{Analytical Techniques}

The major cationic and anionic parameters like magnesium $\left(\mathrm{Mg}^{2+}\right)$, potassium $\left(\mathrm{K}^{+}\right)$, calcium $\left(\mathrm{Ca}^{2+}\right)$, sodium $\left(\mathrm{Na}^{+}\right)$, chloride $\left(\mathrm{Cl}^{-}\right)$, nitrate $\left(\mathrm{NO}_{3}{ }^{-}\right)$, sulfate $\left(\mathrm{SO}_{4}{ }^{2-}\right)$, bicarbonate $\left(\mathrm{HCO}_{3}{ }^{-}\right)$, and fluoride $\left(\mathrm{F}^{-}\right)$were analyzed using the standard analytical procedure described by the American Public Health Association (APHA, 2005). The major cations, magnesium $\left(\mathrm{Mg}^{2+}\right)$ and calcium $\left(\mathrm{Ca}^{2+}\right)$, and the major anions, chloride $\left(\mathrm{Cl}^{-}\right)$, and bicarbonate $\left(\mathrm{HCO}_{3}{ }^{-}\right)$, were analyzed by using a titration technique. A Model 130 digital flame photometer was used for quantitative determination of sodium $\left(\mathrm{Na}^{+}\right)$and potassium $\left(\mathrm{K}^{+}\right)$. Sulphate $\left(\mathrm{SO}_{4}{ }^{2-}\right)$ and nitrate $\left(\mathrm{NO}_{3}{ }^{-}\right)$were analyzed using a UV 1200 Series spectrophotometer. Fluoride ion $\left(\mathrm{F}^{-}\right)$was analyzed using an ionselective electrode.

\section{Quality Assurance}

For quality assurance of analytical procedures, all reagents of analytical grade were used. For making reagents and standards, Millipore ultrapure water was used. Further, the accuracy of analytical results was tested by calculating the ionic balance error according to following equation:

$\mathrm{IBE}=[($ cations - anions $) /($ cations + anions $)] \times 100$

All cations and anions were quantified in meq/l. Most of the data were found to be within the acceptable limit of $\pm 5 \%$.

\section{Spatial Analysis}

Arc-GIS software v.10.2.1 was used to demarcate the study area according to the distribution of fluoride and nitrate in the study area. The various thematic layers were arranged using the IDW (Inverse Distance Weighted) tool. IDW is an important technique which interpolates based on the values of surrounding locations and calculates weights only distance up to the interpolation location as described by Karunanidhi et al. (2020a, b, c, d).

\section{Statistical Analysis and Geochemical Modeling}

Groundwater quality data of the post- and pre-monsoon periods were analyzed using the Spearman correlation method. This statistical analysis was made by using SPSS 16.0 software. To identify the geochemical characteristics of groundwater, a geochemical modeling approach was used. The saturation index (SI) among the water and mineral phases was computed by using the PHREEQC (PH [pH], RE [redox], EQ [equilibrium], C [program in C]) code developed by the US Geological Survey (version 3.2.0). The values of SIs specify the dissolution or precipitation of mineral phases in the aquifer system.

\section{Health Risk Assessment}

The health hazards from exposure to fluoride rich groundwater to the human population in the region were calculated for both fluoride intake and dermal exposures to determine tolerable thresholds. This computation was made according to the methods of the USEPA $(1989,2009)$ to evaluate the health threat through the intake and dermal pathways for children, adult females and adult males. Using the values listed in Table 1, the exposure through intake and dermal pathways were calculated using Eqs. 2 and 3, respectively.
Table 1 Parameter values used for risk assessment in HQ models

\begin{tabular}{lllll}
\hline Parameters & Unit & Children & Women & Men \\
\hline Water intake rate (IR) & $\mathrm{ml} / \mathrm{day}^{-1}$ & 0.73 & 2.12 & 2.5 \\
Average time (AT) & Days & 2190 & 10,950 & 27,010 \\
Exposure frequency (EF) oral & Day/year ${ }^{-1}$ & 365 & 365 & 365 \\
Exposure duration (ED) & Year & 6 & 30 & 74 \\
Body weight (BW) & $\mathrm{Kg}$ & 16.68 & 54.5 & 68.5 \\
Fraction of skin in contact with water $(\mathrm{F})$ & - & 0.4 & 0.4 & 0.4 \\
Skin surface area (SA) & $\mathrm{cm}^{2}$ & 4500 & 10,500 & 15,700 \\
Exposure time (ETs) dermal & $\mathrm{h} / \mathrm{event}^{-}$ & 0.4 & 0.4 & 0.4 \\
Exposure frequency (EF) Dermal & Day/year & 365 \\
Conversion factor $(\mathrm{CF})$ & $1 / \mathrm{cm}^{2}$ & 365 & 365 & 365 \\
Skin adherence factor $(\mathrm{kp})$ & $\mathrm{cm} / \mathrm{h}$ & 0.001 & 0.001 & 0.001 \\
Oral reference dose $(\mathrm{RfD})$ & $\mathrm{mg} / \mathrm{kg}^{-1} / \mathrm{day}^{-1}$ & 0.001 & 0.001 & 0.001 \\
Concentration of element $\left(\mathrm{C}_{\mathrm{w}}\right)$ & $\mathrm{mg} / \mathrm{l}$ & Present study & & 0.06 \\
\hline
\end{tabular}


$E D I_{\text {ingestion }}=\frac{C_{w} \times I R \times E F \times E D}{B W \times A T}$

$E D I_{\text {dermal }}=\frac{C_{w} \times S A \times K_{p} \times F \times E T_{s} \times E F \times E D \times C F}{B W \times A T}$

where: $\mathrm{EDI}_{\text {ingestion }}$ and $\mathrm{EDI}_{\text {dermal }}$ are the daily intake of fluoride $(\mathrm{mg} / \mathrm{kg} /$ day $)$ via ingestion of contaminated drinking water and dermal exposure (i.e. skin absorption), respectively. IR is the drinking water ingestion rate, ED is the exposure duration in years, the $\mathrm{C}_{\mathrm{w}}$ parameter in Eqs. 1 and 2 is the fluoride concentration in groundwater in $\mathrm{mg} / \mathrm{L}$. AT is the average time of exposure in days, BW is the body weight in $\mathrm{kg}, \mathrm{SA}$ is the skin surface area in $\mathrm{cm}^{2}$, F indicates the fraction of the skin surface in contact with contaminated water during bathing, ET is the exposure time through bathing in hours per day, EF is the exposure frequency in days per year, and $\mathrm{Kp}$ is the permeation coefficient in $\mathrm{cm}$ per hour.

Using these data on exposures, the human health hazards through ingestion of drinking water and dermal pathways was determined by calculating EDI and RfD factors. From these parameters, the hazard quotient (HQ) from ingestion and dermal pathways $\left(\mathrm{HQ}_{\text {ingestion }}\right.$ and $\left.\mathrm{HQ}_{\text {dermal }}\right)$ were calculated using Eqs. (4) and (5), respectively.

$H Q_{\text {ingestion }}=\frac{E D I_{\text {ingestion }}}{R f D_{\text {ingestion }}}$

$H Q_{\text {dermal }}=\frac{E D I_{\text {dermal }}}{R f D_{\text {dermal }}}$

where: the reference dose values for $\mathrm{HQ}_{\text {Iingestion }}$ and $\mathrm{HQ}_{\text {dermal }}$ are $0.04 \mathrm{mg} / \mathrm{kg} /$ day. The total hazard index (THI) was calculated using Eq. 6:

$T H I=\frac{H Q_{\text {ingestion }}}{H Q_{\text {dermal }}}$

Based on US EPA's guidelines prescribed for the HQ value, an allowable limit of THI is less than 1 . If THI exceeds 1 , this indicates a hazard greater than the tolerable limit for a noncarcinogenic risk factor.

\section{Results and Discussion}

\section{Physicochemical Parameters}

Table 2 lists the results of the measurement of physiochemical parameters and microbial analysis in the 30 groundwater samples taken from the Sulur region during the post- and pre-monsoon periods. The $\mathrm{pH}$ of groundwater samples 
collected during post- and pre-monsoon ranged from 7.11 to 8.20 and 6.90 to 7.90 , respectively (Table 2), illustrating the slightly alkaline nature of the groundwater. The values of $\mathrm{pH}$ in all groundwater samples fell within the desirable range 6.5-8.5 of pH for drinking water set by the WHO (2017).

The total dissolved solids (TDS) levels ranged from 482 to $3022 \mathrm{mg} / \mathrm{l}$ and 338 to $2237 \mathrm{mg} / \mathrm{l}$ for post- and premonsoon seasons, respectively (Table 1). The elevated TDS values observed in samples collected in the post-monsoon season $(n=8,17)$ declined in samples collected in the premonsoon season at the same locations, which may have been due to the reduced anthropogenic inputs resulted by COVID19 lockdown.

The order of the levels of major ions in the post- and premonsoon samples were $\mathrm{Na}^{+}>\mathrm{Ca}^{2+}>\mathrm{K}^{+}>\mathrm{Mg}^{2+}$ for cations and $\mathrm{HCO}_{3}^{-}>\mathrm{Cl}^{-}>\mathrm{SO}_{4}^{2-}>\mathrm{NO}_{3}^{-} \mathrm{N}^{-}>\mathrm{F}^{-}$for anions (Table 2). The minimum and maximum values of calcium and magnesium are depicted in Table 2 . The average $\mathrm{Na}^{+}$concentration varied slightly among post- and pre-monsoon samples (Table 2), which is probably because $\mathrm{Na}^{+}$mainly comes from geogenic sources. The consumption of high levels of $\mathrm{Na}^{+}$can cause high blood pressure, hyperosmolarity, arteriosclerosis, and oedema (Aravinthasamy et al. 2020a; Karunanidhi et al. 2020a, b, c; Sarath Prasanth et al. 2012). We speculate that percolation of potassium applied in agricultural fertilizers through the soil was responsible for the increase in the concentration of $\mathrm{K}^{+}$in the post-monsoon period.

The recommended limit for $\mathrm{HCO}_{3}^{-}$concentrations is $<600 \mathrm{mg} / \mathrm{l}$ (WHO 2017). Higher amounts of $\mathrm{HCO}_{3}^{-}$were found pre-monsoon samples when compare with post-monsoon samples, which are probably due to ion-exchange and dilution by rainfall infiltration (Karunanidhi et al. 2020c). The foremost source of $\mathrm{Cl}^{-}$in groundwater is through percolation from municipal, domestic, and industrial wastes (Subba Rao et al. 2017; 2019). The $\mathrm{Cl}^{-}$concentration exceeded the prescribed limit at one location (sample no. 14) in pre-monsoon. This may be due to contamination with domestic waste, coupled with a decline in groundwater levels that increased the concentration of this solute in groundwater.

The application of nitrogen fertilizers and gypsum may be important sources of oxyanions in the region. The probable sources for $\mathrm{SO}_{4}^{2-}$ in the study area are fertilizers, bur also may include textile effluents and domestic wastes (Marghade et al. 2019a, 2019b; 2020). However, sulphate ions were within the permissible limits in both the seasons. The $\mathrm{NO}_{3}^{-}$levels in groundwater in the study area ranged from 23 to $180 \mathrm{mg} / \mathrm{l}$ and 10 to $117 \mathrm{mg} / \mathrm{l}$ in samples from the post- and pre-monsoon periods, respectively (Table 2). High concentrations of $\mathrm{NO}_{3}^{-}$in drinking water can cause methemoglobinemia in infants (Arya et al. 2020; Karunanidhi et al. 2020e; Marghade et al. 2019a, $\mathrm{b}, 2011)$. The concentrations of $\mathrm{NO}_{3}^{-}$in groundwater that were greater than the ingestion threshold of $45 \mathrm{mg} / \mathrm{l}$ set by the WHO (2011) occurred in $76.7 \%$ (23) and $43.33 \%$ (13) of the samples collected from the post- and pre-monsoon periods, respectively. The spatial variation maps for $\mathrm{NO}_{3}^{-}$ in samples collected in the post- and pre-monsoon periods are shown in Figs. 2a and 2b, respectively. Figure 2a indicates that a $24.84 \mathrm{~km}^{2}$ area in the study region had groundwater that was safe for drinking and a $558.16 \mathrm{~km}^{2}$ area had groundwater at risk for drinking purposes in the samples collected in the post-monsoon period. However, spatial analysis from the pre-monsoon samples indicated an improvement, as the $\mathrm{NO}_{3}^{-}$safe zone increased to $302.74 \mathrm{~km}^{2}$ and the risk zone declined to $280.26 \mathrm{~km}^{2}$, respectively. Infiltration of contaminated water during the monsoon period probably contributed to high $\mathrm{NO}_{3}^{-}$levels in the January 2020 samples. The drastic decrease in nitrate levels in the pre-monsoon samples relative to the post-monsoon samples is likely due to the cessation of industrial discharges during the COVID-19 lockdown, particularly due to the shutdown of textile industries where $\mathrm{NO}_{3}^{-}$-bearing dyes are used. Reduced nitrate also could be due to a reduction in agriculture activities in the region.

The $\mathrm{F}^{-}$concentrations in groundwater is $60 \%$ and $43.3 \%$ of samples collected in the post- and pre-monsoon periods, respectively, exceeded the safe level of $1.5 \mathrm{mg} / \mathrm{l} \mathrm{set}$ by the WHO (2011). The key source of $\mathrm{F}^{-}$in groundwater is weathering of fluoride containing minerals (Marghade et al. 2019a, 2019b; Karunanidhi et al. 2019). As the study area is an industrial region, possible anthropogenic sources include alloy, steel cast, and semiconductor industries. Based on the $\mathrm{F}^{-}$level, five different contamination categories were identified as low $(<1 \mathrm{mg} / \mathrm{l})$, moderate (1 to $1.5 \mathrm{mg} / \mathrm{l})$, high $(1.5$ to $2 \mathrm{mg} / \mathrm{l})$, very high ( 2 to $2.5 \mathrm{mg} / \mathrm{l})$, and extremely high $(>2.5 \mathrm{mg} / \mathrm{l})$, as defined by Aravinthasamy et al. (2019). As shown in Table 3, $\mathrm{F}^{-}$contamination was low at five locations in the post-monsoon period and at three locations in the pre-monsoon period. Similarly, $\mathrm{F}^{-}$concentrations in the moderate risk category were observed at 7 wells during post-monsoon and at 14 locations during pre-monsoon. High risk concentrations of $\mathrm{F}^{-}$were observed in ten samples and three samples collected during the post- and pre-monsoon periods, respectively. Eight samples of both seasons and two samples of pre-monsoon season represented very high and extremely high-risk categories, respectively (Table 3). None of the samples were within the extremely high category during the post-monsoon period. The spatial distribution maps for fluoride in both monsoon periods are shown in Figs. 3a and $3 b$, respectively. For data from the post-monsoon samples, the risk zone covered an area of $310.74 \mathrm{~km}^{2}$ and the safe zone area was $272.26 \mathrm{~km}^{2}$. Similarly, data from the pre-monsoon samples indicated considerable change, with an area of $341.07 \mathrm{~km}^{2}$ in the risk zone and an area of $241.93 \mathrm{~km}^{2}$ in the safe zone. 

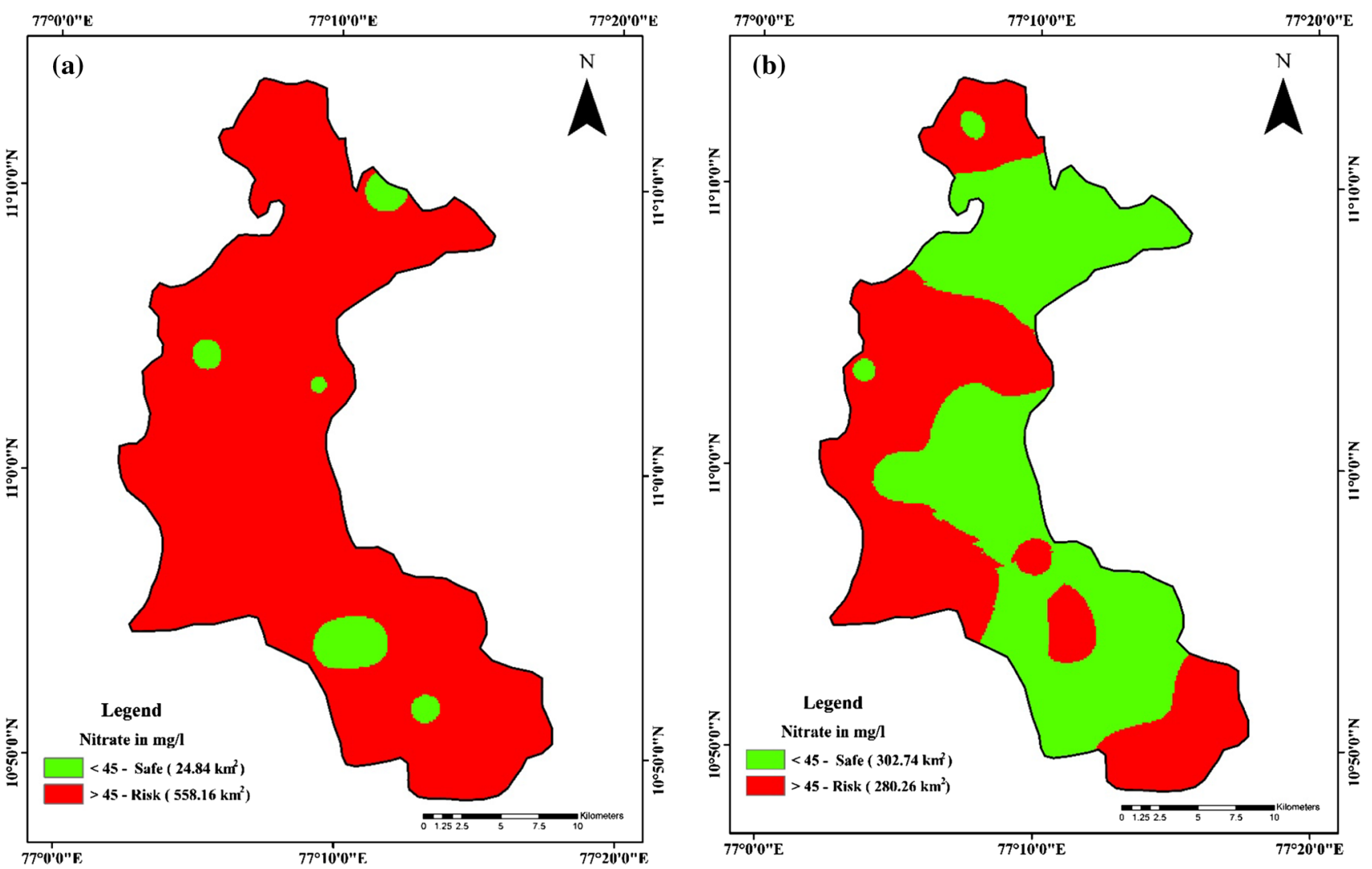

Fig. 2 Comparison of nitrate $\left(\mathrm{NO}_{3}^{-}\right)$concentration for $(\mathbf{a})$ post-monsoon and (b) pre-monsoon groundwater samples

\section{Groundwater Types}

The water categorization hinges on the ionic composition of groundwater. Examination of a trilinear Piper diagram (Piper, 1944) in Fig. 4 shows that the groundwater in 87.6\% and $60 \%$ of samples have $\mathrm{Na}^{+}+\mathrm{K}^{+}$as dominant cations in the post- and pre-monsoon periods, respectively. Approximately $66.7 \%$ of the samples collected in both periods had bicarbonate as the dominant anion. The minimization of anthropogenic inputs due to a lockdown period and reverse ion-exchange probably resulted in a drop in the dominancy of $\mathrm{Na}^{+}+\mathrm{K}^{+}$in $27.6 \%$ of the samples collected in the premonsoon period. Reverse ion-exchange is evidenced by increased concentration in the pre-monsoon samples.

In the post-monsoon samples, $57 \%$ of the samples belonged to the $\mathrm{Na}-\mathrm{HCO}_{3}-\mathrm{Cl}$ water types, whereas $20 \%$ belonged to the $\mathrm{Na}-\mathrm{Cl}$ water type and the remaining samples belonged to the $\mathrm{Ca}-\mathrm{Mg}-\mathrm{HCO}_{3}$ type, except for only one sample of the $\mathrm{Ca}-\mathrm{Mg}-\mathrm{Cl}$ type. The water types identified for the pre-lockdown (i.e. post-monsoon) period that are rich in sodium and chloride highlighted the impact of anthropogenic inputs on water quality. The anthropogenic inputs such as sequestering agents and water softening processes used within the textile industries, as well as leaching from solid wastes were the important sources in the study area. In addition, the probable reasons for $\mathrm{Na}^{+}$enhancement in groundwater in the study area particularly during postmonsoon season may be due to geogenic processes (e.g., ion exchange processes and silicate weathering). In the premonsoon samples, $43.3 \%$ of the samples were found to be of the $\mathrm{Ca}-\mathrm{Mg}-\mathrm{HCO}_{3}$ type, $30 \%$ were of the $\mathrm{Ca}-\mathrm{Mg}-\mathrm{Cl}$ type of water, and the remaining samples were of the $\mathrm{Na}-\mathrm{HCO}_{3}-$ $\mathrm{Cl}$ type of water (Fig. 4). The reversion back of $\mathrm{Na}-\mathrm{Cl}$ and $\mathrm{Na}-\mathrm{HCO}_{3}-\mathrm{Cl}$ water types in samples from the post-monsoon period into $\mathrm{Ca}-\mathrm{HCO}_{3}$ type in samples from the pre-monsoon period illustrates that there was a drastic decrease in groundwater pollution. This improvement in groundwater quality is consistent with extensive reductions in anthropogenic inputs, such as complete shutdown of industries and slightly reduced agricultural activities throughout the lockdown period.

\section{Geogenic Signatures}

In general, the hydrochemical characteristics of groundwater account for the quality of groundwater. Various geogenic factors, such as solute aqueous phase interactions and ion exchange processes, that occur in groundwater are largely responsible for the quality of groundwater (Arya et al. 2019). The quality is further altered by climatic factors to some extent (e.g., recharge from increased rainfall) and ongoing 


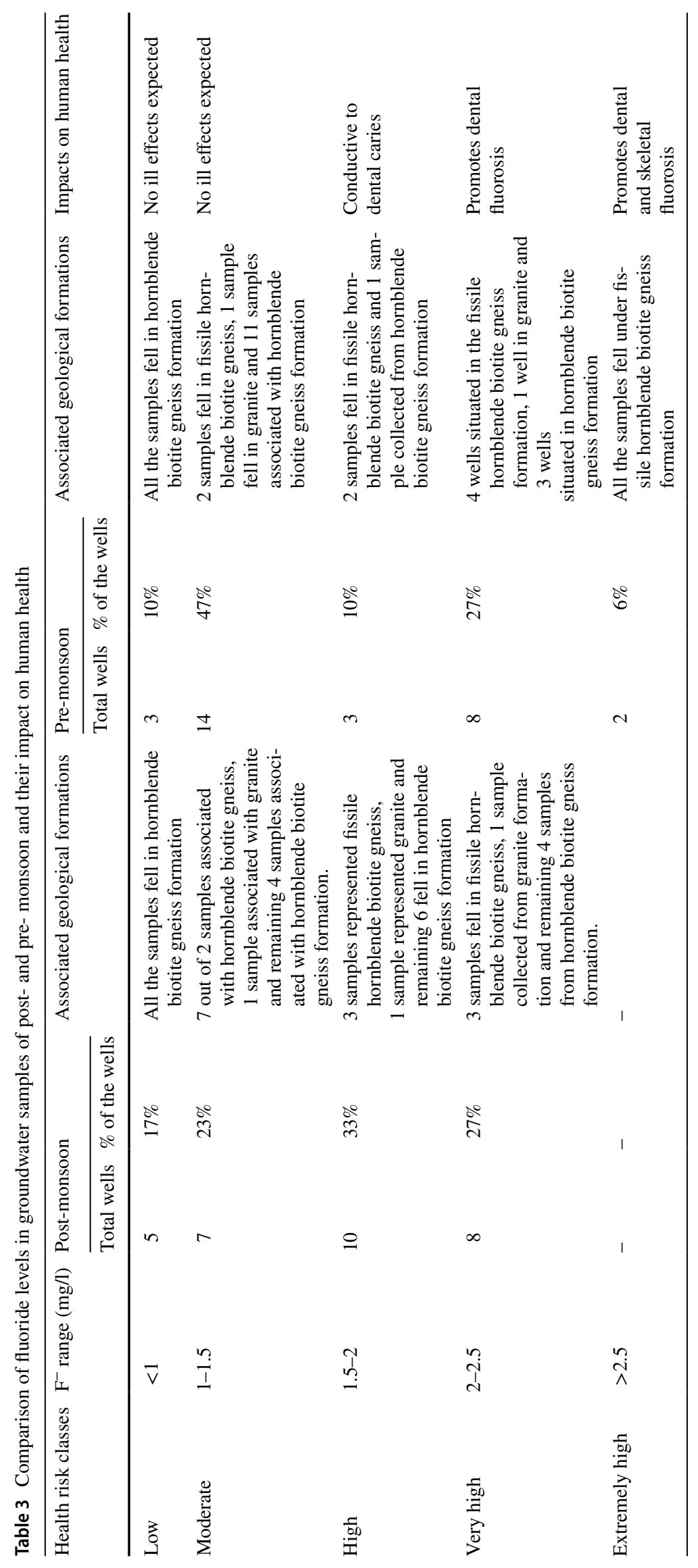



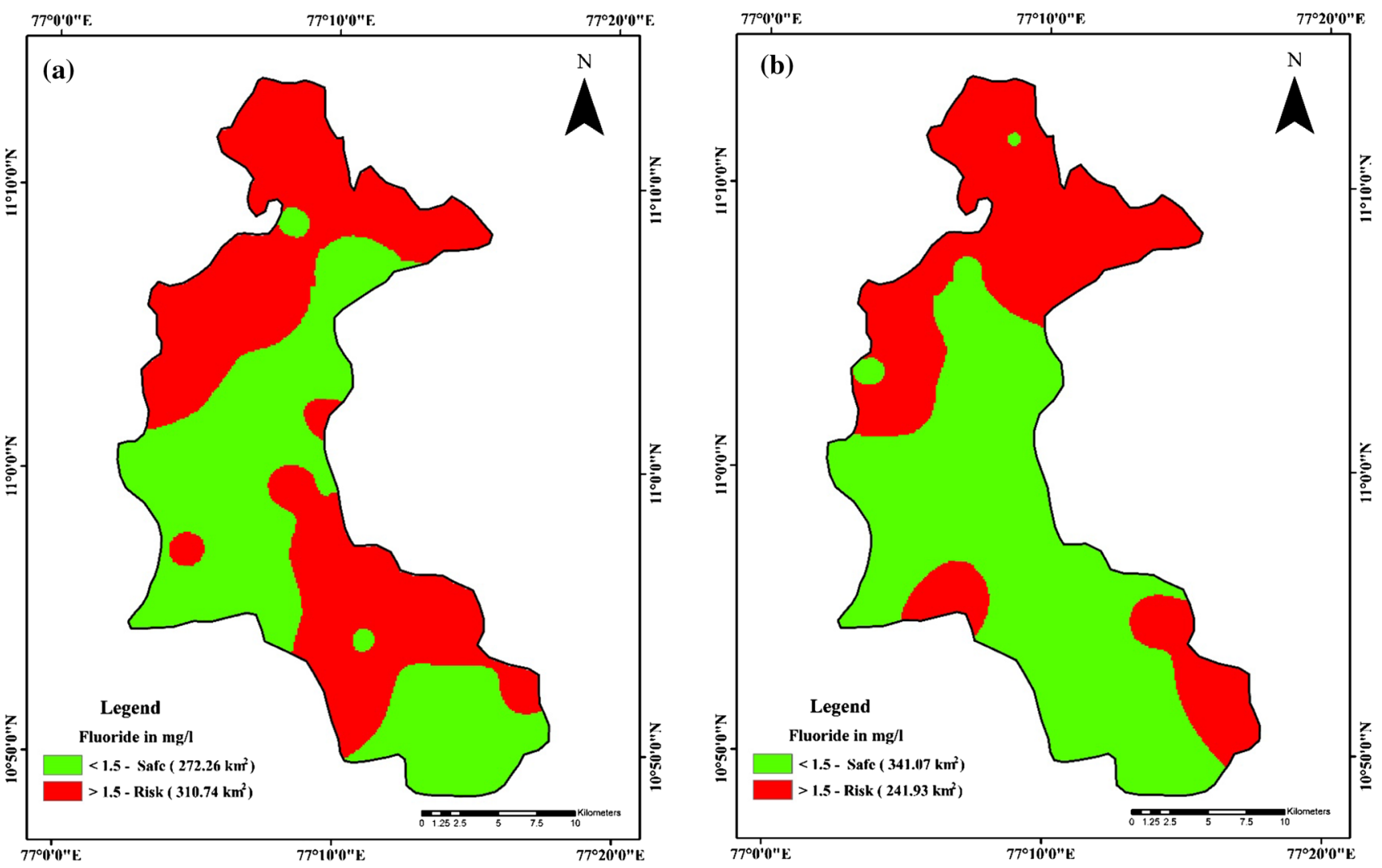

Fig. 3 Comparison of fluoride $\left(\mathrm{F}^{-}\right)$concentration for (a) post-monsoon and (b) pre-monsoon groundwater samples

anthropogenic factors. The molar ratios and scatter plots among the ions are generally utilized as geochemical characteristics to indicate the influence of geogenic and anthropogenic sources and the influence of land use patterns on the hydrochemistry of the groundwater (Thilagavathi et al. 2015; Marghade et al. 2019a).

The ionic ratios calculated for $\mathrm{Na}^{+} /\left(\mathrm{Na}^{+}+\mathrm{Cl}^{-}\right)$lie in the range of 0.42 to 0.80 and 0.12 to 0.80 for samples collected in the post- and pre-monsoon seasons, respectively. A value of $\mathrm{Na}^{+} /\left(\mathrm{Na}^{+}+\mathrm{Cl}^{-}\right)$greater than 0.5 indicates the contributions of sources other than the halite minerals, such as plagioclase mineral weathering, ion exchange reactions between the aqueous phase and mineral phase, and anthropogenic inputs (Naderi et al. 2020; Singh et al. 2018). In 73\% of samples collected in the post-monsoon, the concentrations of $\mathrm{Na}^{+}$were greater than $\mathrm{Cl}^{-}$, highlighting the role of the natural softening process (Eq. 7), albite (plagioclase) weathering (Eq. 8), and possible inputs from textile industries:

$$
\begin{aligned}
& \mathrm{Ca}^{2+}+\mathrm{Na} \text { - Clay } \rightarrow \mathrm{Na}^{+}+\mathrm{Ca} \text { - Clay } \\
& 2 \mathrm{Na}^{+}\left[\mathrm{AlSi}_{3} \mathrm{O}_{8}+2 \mathrm{CO}_{2}\right]^{-}+11 \mathrm{H}_{2} \mathrm{O} \rightarrow 2 \mathrm{Na}^{+}+ \\
& 2 \mathrm{HCO}_{3}^{-}+\mathrm{Al}_{2} \mathrm{Si}_{2} \mathrm{O}_{5}(\mathrm{OH})_{4}+\mathrm{Mg}^{2+}+4 \mathrm{H}_{4} \mathrm{SiO}_{4} \text { Albite }
\end{aligned}
$$

The plot of $\mathrm{Na}^{+}$versus $\mathrm{Cl}^{-}$(Fig. 5a) shows that the salinity increased in groundwater samples collected during post-monsoon; $83 \%$ of the samples fell below the 1:1 line, indicating the effect of ion exchange processes and silicate weathering, consistent with predictions from the $\mathrm{Na}^{+} /$ $\left(\mathrm{Na}^{+}+\mathrm{Cl}^{-}\right)$ratio. This may be due to recharging of aquifers through rain water which accelerates the kinetics of albite weathering and natural softening through ion exchange processes (i.e., Equation 7) (Subramani et al. 2013). Conversely, in the pre-monsoon samples, $66 \%$ of the samples were above the $1: 1$ line in the $\mathrm{Na}^{+}$versus $\mathrm{Cl}^{-}$plot. This anomalous rise in $\mathrm{Cl}^{-}$concentration during pre-monsoon period is probably due to enhanced weathering of amphiboles and biotite minerals along with accelerated reverse ion exchange (Eq. 9) associated with the dry climate. It could also be attributed to evaporation of soil pore water, which is associated with an increase in chloride concentration, and displacement of this soil water into groundwater. This is further supported by the $\mathrm{Na}^{+} / \mathrm{Cl}^{-}$versus EC plot (Fig. 5b), in which $73 \%$ of the samples had the molar ratio greater than one $\left(\mathrm{Na}^{+} / \mathrm{Cl}^{-}>1\right)$, consistent with a process of albite weathering and natural softening from ion exchange processes, along with high anthropogenic inputs (Subramani et al. 2009). Conversely, during the 


\section{Piper diagram}

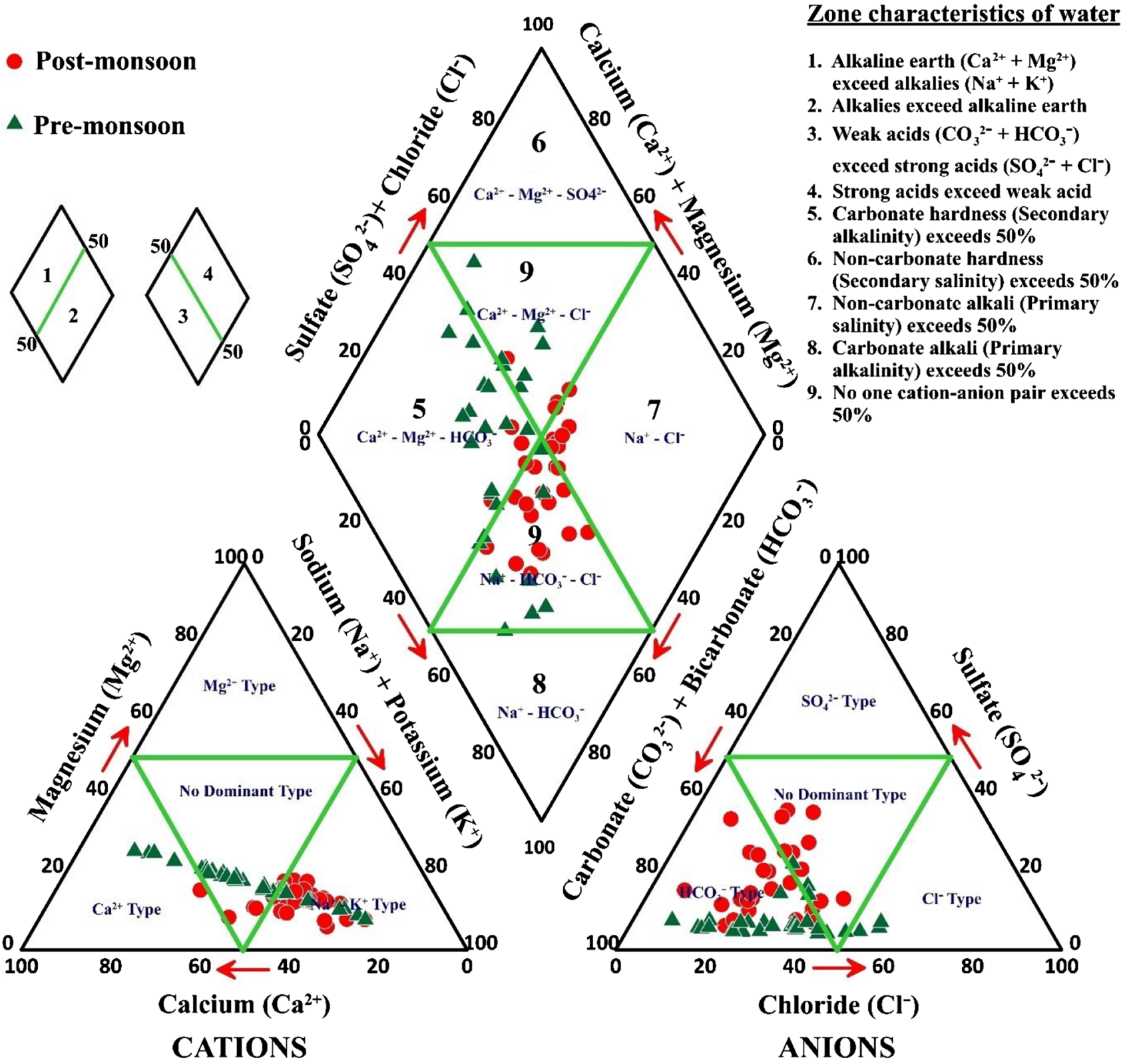

Fig. 4 Piper diagram showing the mechanism of geochemical changes in the post- and pre-monsoon groundwater samples

post-lockdown period, $77 \%$ of the groundwater samples fell below the $\mathrm{Na}^{+} / \mathrm{Cl}^{-}$ratio of 1 (Fig. 5b), consistent with biotite weathering and reverse ion exchange processes.

$2 \mathrm{Na}^{+}+\mathrm{Ca}^{2+}$ - Clay $\rightarrow \mathrm{Ca}^{2+}+\mathrm{Na}$ - Clay

Approximately $57 \%$ of the samples fell under the 1:1 line on the $\mathrm{Ca}^{2+}+\mathrm{Mg}^{2+}$ versus $\mathrm{HCO}_{3}{ }^{-}+\mathrm{SO}_{4}{ }^{2-}$ plot (Fig. 5c) in samples collected during the post-monsoon period, signifying albite (silicate) and carbonate weathering (Marghade et al. 2019a, 2019b; Hussin et al. 2016). The wide deviation of sampling points from the 1:1 line in the lockdown sampling period (i.e., pre-monsoon) indicates that there was less dissolution of carbonates and cation ion exchange, which facilitate reverse ion exchange process. This finding is further supported by the $\mathrm{Ca}^{2+}+\mathrm{Mg}^{2+}$ versus $\mathrm{HCO}_{3}{ }^{-}$plot (Fig. 5d) and $\mathrm{Ca}^{2+}$ versus $\mathrm{Na}^{+}$(Fig. 5e). The $\mathrm{Ca}^{2+}$ and $\mathrm{Na}^{+}$ bivariate plot indicates that ion exchange/silicate weathering is an important process nullifies the probability of weathering carbonates in post-monsoon seasons. Conversely, the 


\section{Post-monsoon}

\section{Pre-monsoon}
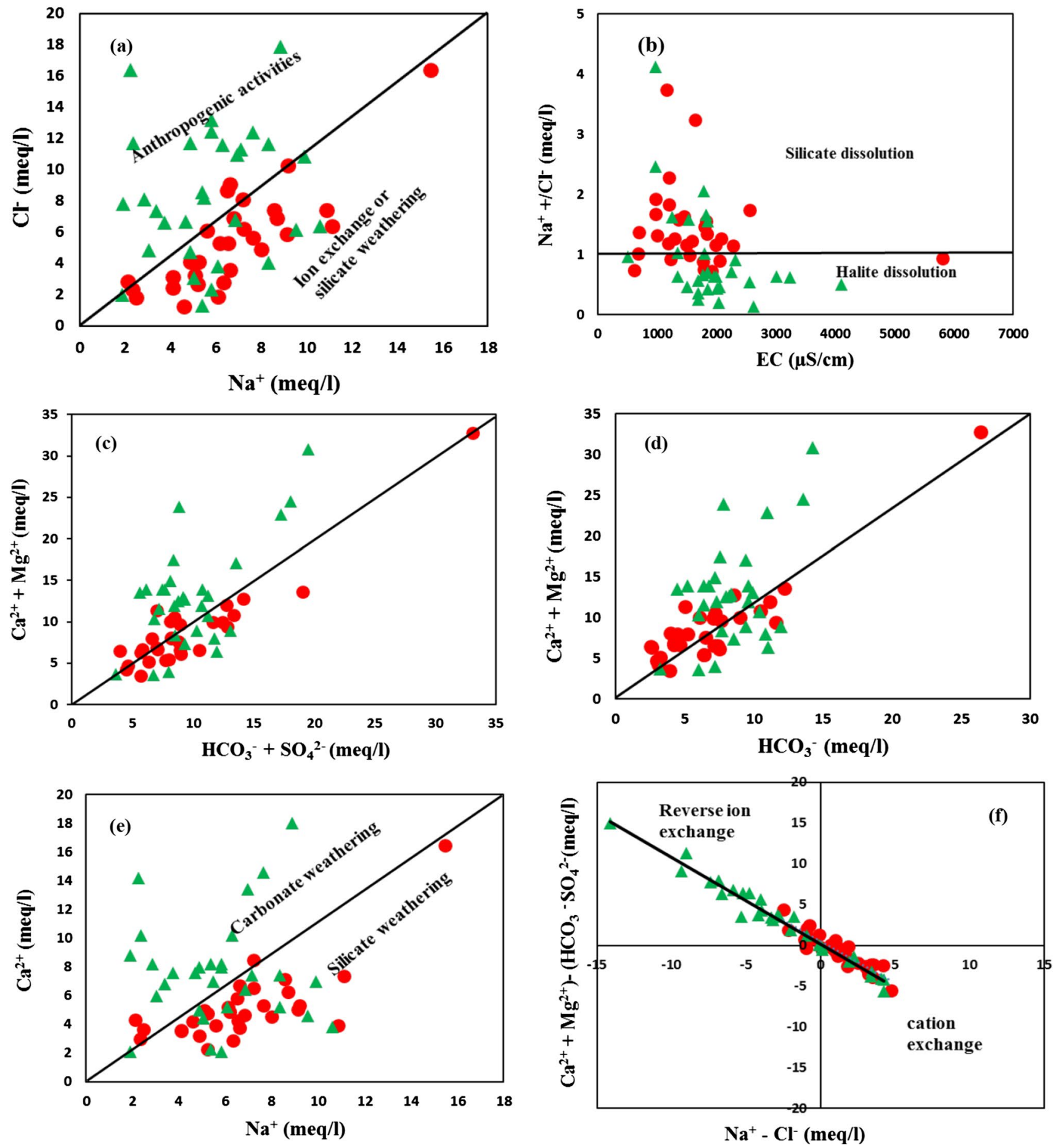

Fig. 5 Bivariate plots showing various hydrogeochemical alterations occurred in the groundwater environment in post- and pre-monsoon a $\mathrm{Na}^{+}$vs. $\mathrm{Cl}^{-}$b $\mathrm{Na}+/ \mathrm{Cl}-$ vs, $\mathrm{EC}, \mathrm{c} \mathrm{Ca}^{2+}+\mathrm{Mg}^{2+}$ vs. $\mathrm{HCO}_{3}{ }^{-}+\mathrm{SO}_{4}{ }^{2-}$ d

$\mathrm{Ca}^{2+}+\mathrm{Mg}^{2+}$ vs $\mathrm{HCO}_{3}{ }^{-}$e $\mathrm{Ca}^{2+}$ vs $\mathrm{Na}^{+} \mathbf{f} \mathrm{Ca}^{2+}-\mathrm{Mg}^{2+}-\mathrm{SO}_{4}{ }^{2-}-\mathrm{HCO}_{3}$ - vs. $\mathrm{Na}^{+}-\mathrm{Cl}^{-}$ 
scattering of points above the 1:1 line supports the influence of the process of carbonate weathering along with reverse ion exchange. Approximately $70 \%$ of sampling point on the plot of $\mathrm{Ca}^{2+}-\mathrm{Mg}^{2+}-\mathrm{SO}_{4}{ }^{2-}-\mathrm{HCO}_{3}{ }^{-}$versus $\mathrm{Na}^{+}-\mathrm{Cl}^{-}$(Fig. 5f), in post- monsoon samples fell in the range favoring cation exchange processes, whereas $66 \%$ of the samples from the pre-monsoon samples fell in the range favoring reverse ion exchange processes.

Higher fluoride concentrations in groundwater of geogenic origin are commonly associated with granitic gneisses, syenites, granodiorites, quartz-monzonites, and hornblende-biotite-gneisses (Edmunds and Smedley 2005; Karunanidhi et al. 2020a, b, c, d; Mukherjee et al. 2019). Fluoride is commonly present in minerals, such as fluorapatite $\left[\mathrm{Ca}_{5}\left(\mathrm{PO}_{4}\right)_{3} \mathrm{OH}, \mathrm{F}\right]$, topaz $\left[\mathrm{Al}_{2}\left(\mathrm{SiO}_{4}\right) \mathrm{F}_{2}\right]\left(\mathrm{CaF}_{2}\right)$, cryolite $\left(\mathrm{Na}_{3} \mathrm{AlF}_{6}\right)$, villiaumite $(\mathrm{NaF})$, amphiboles, and micas (Adimalla and Qian 2019; Mukherjee et al. 2019). Because the groundwater of the study region is predominantly alkaline, it favors the dissolution of fluoride bearing minerals in rocks. The Eq. 10 for biotite weathering indicates that $\mathrm{OH}^{-}$radicals in the groundwater with higher $\mathrm{pH}$ values are exchanged with $\mathrm{F}^{-}$, resulting in fluoride enriched groundwater.

$$
\mathrm{KMg}_{3}\left(\mathrm{AlSi}_{3} \mathrm{O}_{10}\right) \mathrm{F}_{2}+2 \mathrm{OH}^{-} \rightarrow \mathrm{KMg}_{3}\left(\mathrm{AlSi}_{3} \mathrm{O}_{10}\right)(\mathrm{OH})_{2}+2 \mathrm{~F}^{-}
$$

\section{Anthropogenic Indicators}

The correlations between different ions and with TDS are used as anthropogenic indicators to show the impact of fertilizers, discharges of wastewater effluents, and leaching from municipal solid wastes. A correlation coefficient ( $\mathrm{r}$ ) value below 0.3 specifies the correlation as "weak," an $r$-value of 0.3 to 0.7 identifies the correlation as "moderate," and an $r$-value greater than 0.7 identifies the correlation as "strong" (Emenike et al. 2018). In samples collected during the postmonsoon period, TDS was positively correlated with $\mathrm{Na}^{+}$ $(r=0.89)$ and $\mathrm{K}^{+}(r=0.95)$, indicating a higher contribution of pollution from anthropogenic activities for these cations (Fig. 6). Also, correlations between $\mathrm{Cl}^{-}$and TDS ( $\left.r=0.85\right)$ and EC $(r=0.86)$ indicate $\mathrm{Cl}^{-}$enrichment due to anthropogenic activities (Ahada and Suther 2018; Marghade et al. 2011). TDS was positively correlated with $\mathrm{SO}_{4}{ }^{2-}(0.63)$, and $\mathrm{NO}_{3}{ }^{-}(r=0.34)$, consistent with anthropogenic inputs due to industries, domestic waste, and leaching from irrigation. The infiltration of rainwater, coupled with fertilizer usage in agricultural areas, leaching of industrial and municipal wastes and discharges of domestic sewage into surface waters are important sources of groundwater contamination.
In pre-monsoon samples (i.e., during lockdown), the strong positive correlation between TDS and $\mathrm{K}^{+}(r=0.78)$ and $\mathrm{Na}^{+}(r=0.77)$ indicates physiochemical reactions, such as ion exchange and oxidation - reduction in the aquifer system (Udayalaxami et al. 2010) (Fig. 7). The weak positive correlation of $\mathrm{NO}_{3}^{-}$with $\mathrm{Cl}^{-}(r=0.29)$ indicates that nitrate pollution of groundwater was mostly affected by surface activities, such as domestic and industrial wastes dumped on the surface (Venkatesan et al. 2020).

\section{Saturation Index}

The saturation index (SI) based on mineral solid phases such as gypsum $\left(\mathrm{CaSO}_{4} \cdot 2 \mathrm{H}_{2} \mathrm{O}\right)$, fluorite $\left(\mathrm{CaF}_{2}\right)$, calcite $\left(\mathrm{CaCO}_{3}\right)$, halite $(\mathrm{NaCl})$, anhydrite $\left(\mathrm{CaSO}_{4}\right)$, dolomite $\left(\mathrm{CaMg}\left(\mathrm{CO}_{3}\right)_{2}\right)$, and aragonite $\left(\mathrm{CaCO}_{3}\right)$ was computed using the USGS software, PHREEQC (version 3.2.0) to evaluate the impact of climatic and solubility conditions on the groundwater environment (Table 4). The source for the high $\mathrm{SO}_{4}{ }^{2-}$ and $\mathrm{Ca}^{2+}$ concentrations in the groundwater is mainly anhydrite dissolution, as indicated by the negative SI values in samples collected in the post- and pre-monsoon periods (i.e., -2.2239 to -1.219 and -2.7214 to -1.1813$)$. The negative values in the post- $(-1.987$ to -0.983$)$ and pre-monsoon samples $(-2.484$ to -0.944$)$ indicate the dissolution effect of gypsum in the groundwater system (Table 4). The SI value for dolomite $\left(\mathrm{CaMg}\left(\mathrm{CO}_{3}\right)_{2}\right)$ and calcite $\left(\mathrm{CaCO}_{3}\right)$ in post-monsoon samples varies from -0.9905 to 2.2836 and -0.3172 to 1.1057 . The SI dolomite positive values in $63 \%$ of samples indicate calcium precipitation ( $\mathrm{Li}$ et al. 2018). The positive saturation index for calcite signifies precipitation of calcite in $70 \%$ and $90 \%$ of the samples collected during the post- and premonsoon periods, respectively, reflect $\mathrm{Na}^{+}$enhancement in groundwater. The negative SI values of halite $(\mathrm{NaCl})$ in all samples collected during the post- and pre-monsoon periods highlight the role of dissolution of halite minerals, leading to $\mathrm{Na}^{+}$enrichment of groundwater.

\section{Health Risk Assessment for Fluoride}

In the Sulur region, fluoride is present in groundwater collected from many locations at concentrations that are greater than the allowable limits for drinking water set by the WHO. Hence, it is vital to conduct the health risk survey by calculating hazard quotient (HQ) for fluoride based on these regulatory limits. HQ values for noncarcinogenic risks from ingestion of contaminated drinking water and exposure through dermal pathways and total hazard index (THI) values were calculated for children, adult women, and adult men (Table 5). Table 5 presents minimum, maximum, and average values of $\mathrm{HQ}$ and THI for the above categories. The values indicate that dermal 


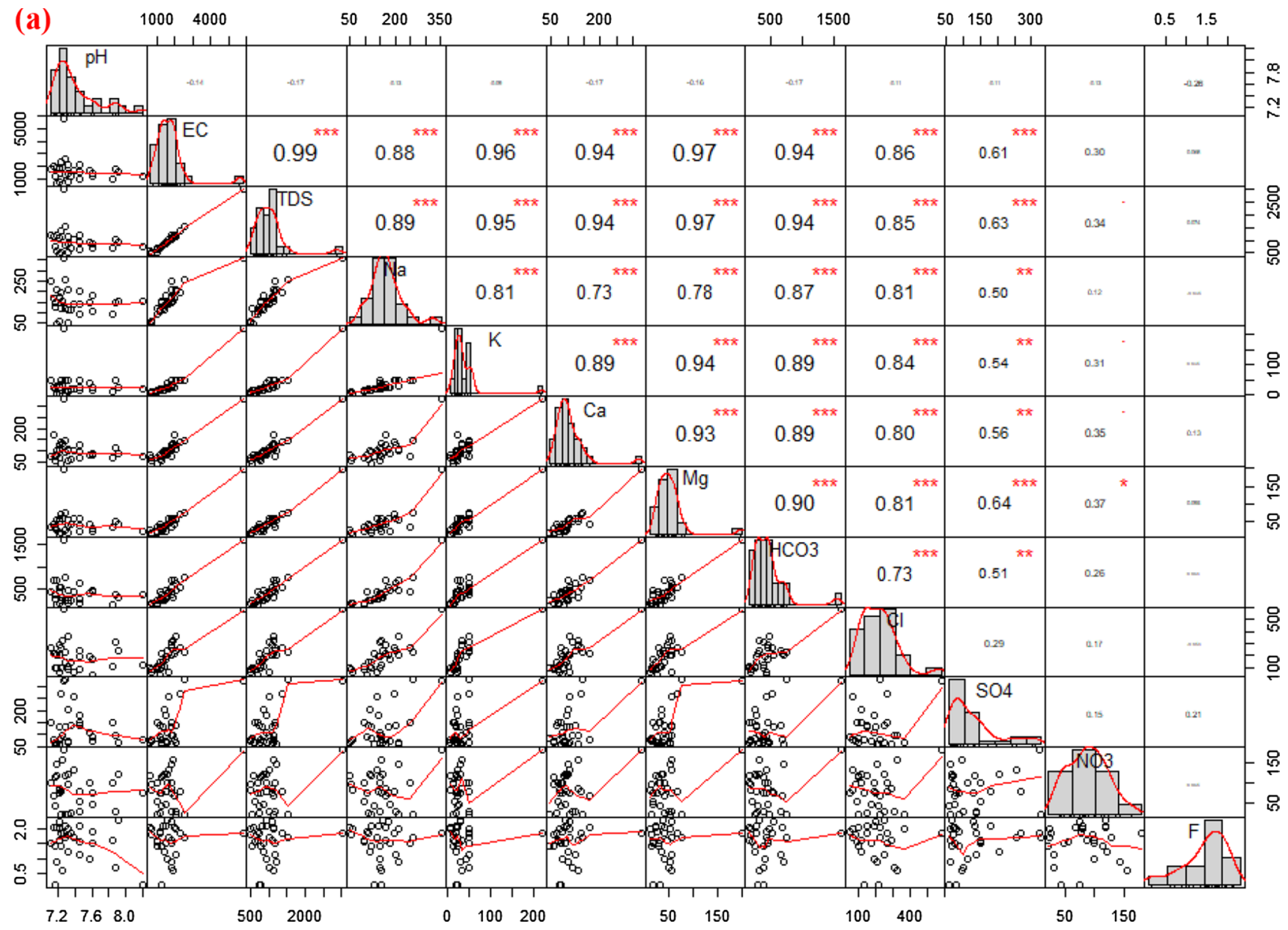

Fig. 6 Spearman correlation coefficient matrix expresses the relationship among various major physicochemical parameters in the post-monsoon groundwater samples

contact is much lower in terms of hazards from exposure to fluoride than the hazards of ingestion of fluoride in drinking water.

The THI values for ingestion of fluoride ranged from 0.074 to 1.696 (mean 1.127) for children, 0.065 to 1.491 (mean 0.991 ) for adult women, and 0.061 to 1.399 (mean 0.929) for adult men. These THI results indicate that $73 \%, 60 \%$, and $50 \%$ of the samples were higher than the permissible limits for health risks from ingestion of fluoride by children, women, and men, respectively. Based on this study, children are more at risk than the adult women and men. The elevated noncarcinogenic risk for children is mainly due to the lesser body weights (BW) of children compared with adult women and men (i.e., in Eq. 2 and 3, BW is in denominator).

\section{Conclusions}

Human health risks from consumption of contaminated groundwater in this region of southern India are mainly due to high fluoride concentrations, which are primarily from geogenic sources. However, fluoride levels also could be influenced by industrial sources. Higher levels of fluoride contamination in groundwater observed in the post-monsoon samples collected in January 2020 are consistent with the influence of infiltration of rainwater during the monsoon on the release of geogenic fluoride. Fluoride contamination had declined in the samples collected in the pre-monsoon period (i.e., May 2020). The majority 


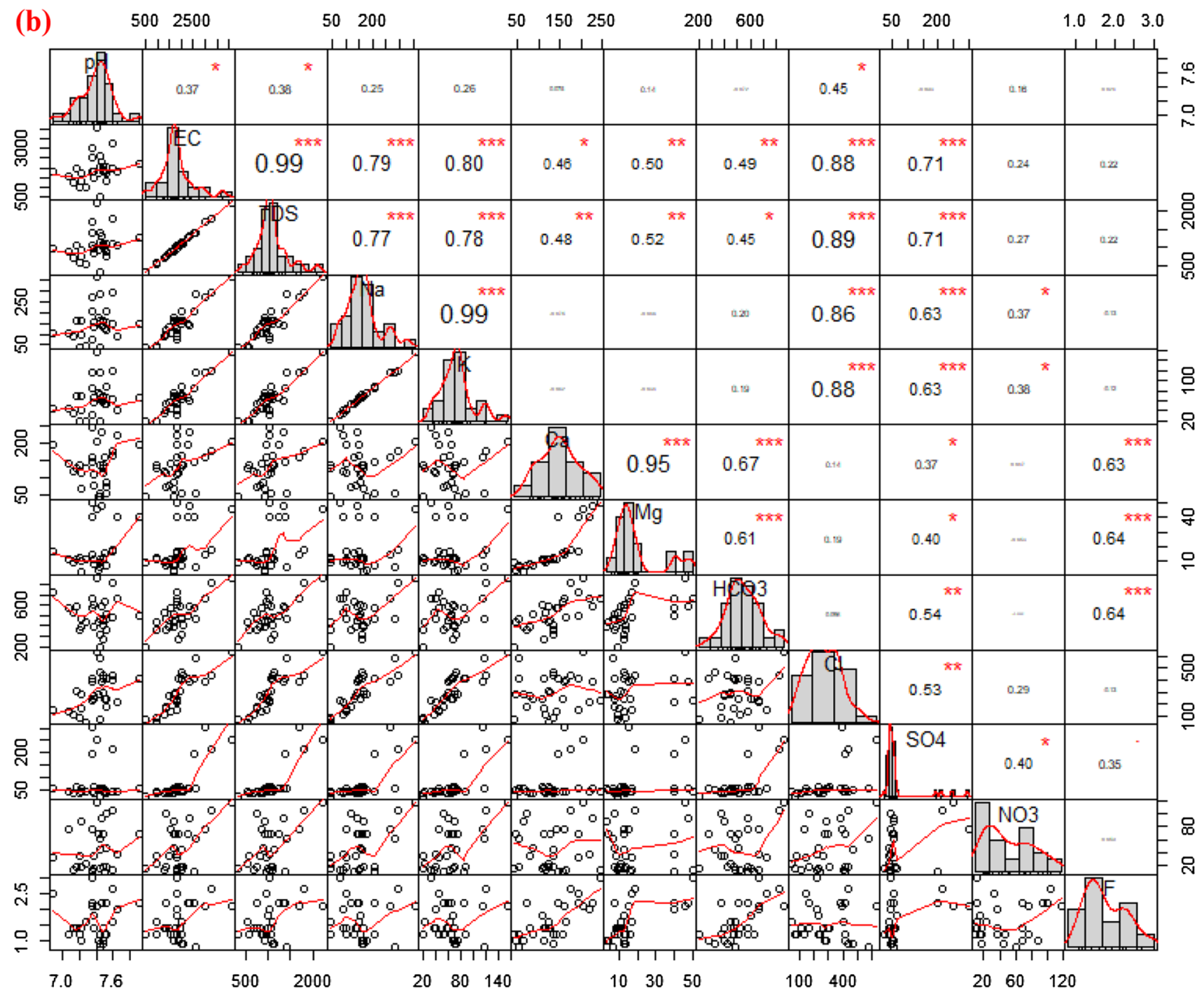

Fig. 7 Spearman correlation coefficient matrix expresses the relationship among various major physicochemical parameters in the pre-monsoon groundwater samples

of groundwater samples contained fluoride concentrations at levels higher than the permissible limits, with children at the greatest risk of fluorosis. In this investigation, high EC and TDS values in groundwater indicated pollution from anthropogenic sources in the study area. A decrease in the nitrate concentration by approximately $33.4 \%$ in samples collected in the pre-monsoon period (May 2020) relative to the post-monsoon period (January 2020) was probably due to the shutdown of industries and reduced agricultural activities that occurred in the study region as a result of the COVID-19 lockdown. Similarly, the percentage of groundwater samples that were unsuitable for human consumption due to high ionic loads in the post-monsoon period (i.e., before lockdown) was relatively reduced in the pre-monsoon period (i.e., during lockdown). Based on the Piper trilinear diagram, groundwater had chemically changed from $\mathrm{Na}-\mathrm{HCO}_{3}-\mathrm{Cl}$ and $\mathrm{Na}-\mathrm{Cl}$ to the $\mathrm{Ca}-\mathrm{HCO}_{3}$ type during the pre-monsoon period. An increase in bicarbonates signified a considerable improvement in groundwater quality during the lockdown period. Geogenic indicators confirmed the influence of mineral weathering, carbonate dissolution, and reverse ion exchange processes on groundwater quality, in addition to the anthropogenic inputs. These findings are further supported by the changes in the saturation index computed for the post- and pre-monsoon samples. Overall, this study showed the positive effects of reduced human activities on groundwater quality. It is evident from the influence of the lockdown that controlling the inputs of pollutants from industries and agriculture can have a positive benefit on groundwater quality and the environment in general. 


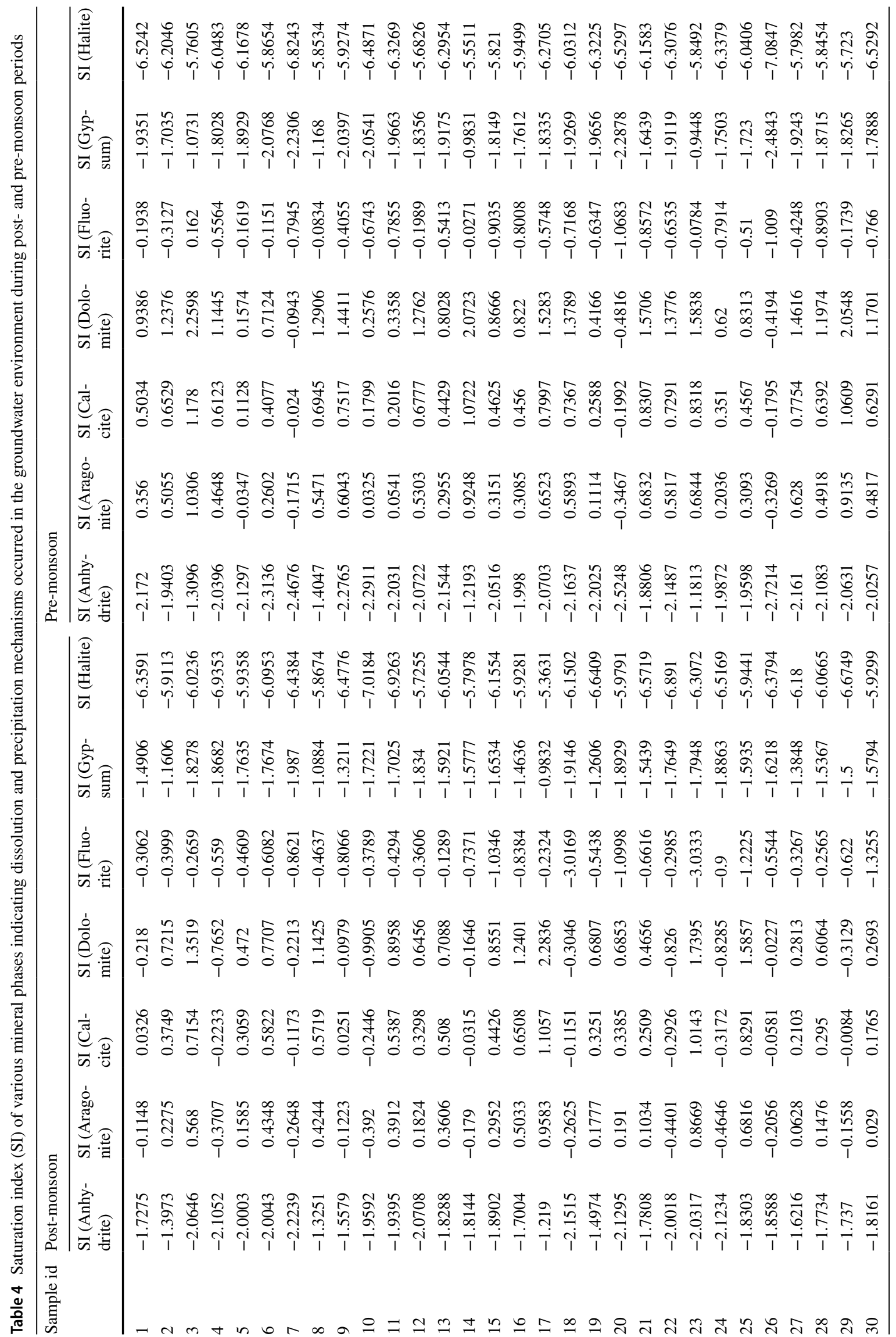


Table 5 Noncarcinogenic health risks of fluoride based on ingestion and dermal pathways

\begin{tabular}{|c|c|c|c|c|c|c|c|c|c|}
\hline \multirow[t]{2}{*}{ S1. No } & \multicolumn{3}{|l|}{$\mathrm{HQ}_{\text {ingestion }}$} & \multicolumn{3}{|l|}{$\mathrm{HQ}_{\text {dermal }}$} & \multicolumn{3}{|l|}{ THI } \\
\hline & Children & Adult female & Adult male & Children & Adult female & Adult male & Children & Adult female & Adult male \\
\hline 1 & 0.074 & 0.065 & 0.061 & $3.75 \mathrm{E}-06$ & $5.85 \mathrm{E}-06$ & $5.46 \mathrm{E}-06$ & 0.074 & 0.065 & 0.061 \\
\hline 2 & 0.442 & 0.389 & 0.365 & $2.25 \mathrm{E}-05$ & $3.51 \mathrm{E}-05$ & $3.28 \mathrm{E}-05$ & 0.442 & 0.389 & 0.365 \\
\hline 3 & 1.696 & 1.491 & 1.399 & $8.63 \mathrm{E}-05$ & $1.35 \mathrm{E}-04$ & $1.26 \mathrm{E}-04$ & 1.696 & 1.491 & 1.399 \\
\hline 4 & 1.313 & 1.154 & 1.083 & $6.68 \mathrm{E}-05$ & $1.04 \mathrm{E}-04$ & $9.72 \mathrm{E}-05$ & 1.313 & 1.154 & 1.083 \\
\hline 5 & 1.180 & 1.037 & 0.973 & $6.00 \mathrm{E}-05$ & $9.36 \mathrm{E}-05$ & $8.74 \mathrm{E}-05$ & 1.180 & 1.037 & 0.973 \\
\hline 6 & 1.113 & 0.979 & 0.918 & $5.66 \mathrm{E}-05$ & $8.83 \mathrm{E}-05$ & $8.25 \mathrm{E}-05$ & 1.114 & 0.979 & 0.919 \\
\hline 7 & 1.032 & 0.908 & 0.852 & $5.25 \mathrm{E}-05$ & $8.19 \mathrm{E}-05$ & $7.65 \mathrm{E}-05$ & 1.032 & 0.908 & 0.852 \\
\hline 8 & 1.254 & 1.102 & 1.034 & $6.38 \mathrm{E}-05$ & $9.95 \mathrm{E}-05$ & $9.28 \mathrm{E}-05$ & 1.254 & 1.102 & 1.034 \\
\hline 9 & 0.664 & 0.583 & 0.547 & $3.38 \mathrm{E}-05$ & $5.27 \mathrm{E}-05$ & $4.92 \mathrm{E}-05$ & 0.664 & 0.584 & 0.547 \\
\hline 10 & 0.074 & 0.065 & 0.061 & $3.75 \mathrm{E}-06$ & $5.85 \mathrm{E}-06$ & $5.46 \mathrm{E}-06$ & 0.074 & 0.065 & 0.061 \\
\hline 11 & 1.401 & 1.232 & 1.156 & $7.13 \mathrm{E}-05$ & $1.11 \mathrm{E}-04$ & $1.04 \mathrm{E}-04$ & 1.401 & 1.232 & 1.156 \\
\hline 12 & 1.460 & 1.284 & 1.204 & $7.43 \mathrm{E}-05$ & $1.16 \mathrm{E}-04$ & $1.08 \mathrm{E}-04$ & 1.460 & 1.284 & 1.204 \\
\hline 13 & 1.527 & 1.343 & 1.260 & $7.77 \mathrm{E}-05$ & $1.21 \mathrm{E}-04$ & $1.13 \mathrm{E}-04$ & 1.527 & 1.343 & 1.260 \\
\hline 14 & 1.121 & 0.985 & 0.925 & $5.70 \mathrm{E}-05$ & $8.89 \mathrm{E}-05$ & $8.30 \mathrm{E}-05$ & 1.121 & 0.986 & 0.925 \\
\hline 15 & 0.737 & 0.648 & 0.608 & $3.75 \mathrm{E}-05$ & $5.85 \mathrm{E}-05$ & $5.46 \mathrm{E}-05$ & 0.737 & 0.648 & 0.608 \\
\hline 16 & 0.811 & 0.713 & 0.669 & $4.13 \mathrm{E}-05$ & $6.44 \mathrm{E}-05$ & $6.01 \mathrm{E}-05$ & 0.811 & 0.713 & 0.669 \\
\hline 17 & 1.373 & 1.207 & 1.133 & $6.98 \mathrm{E}-05$ & $1.09 \mathrm{E}-04$ & $1.02 \mathrm{E}-04$ & 1.373 & 1.207 & 1.133 \\
\hline 18 & 1.549 & 1.361 & 1.277 & $7.88 \mathrm{E}-05$ & $1.23 \mathrm{E}-04$ & $1.15 \mathrm{E}-04$ & 1.549 & 1.362 & 1.277 \\
\hline 19 & 1.254 & 1.102 & 1.034 & $6.38 \mathrm{E}-05$ & $9.95 \mathrm{E}-05$ & $9.28 \mathrm{E}-05$ & 1.254 & 1.102 & 1.034 \\
\hline 20 & 0.885 & 0.778 & 0.730 & $4.50 \mathrm{E}-05$ & $7.02 \mathrm{E}-05$ & $6.55 \mathrm{E}-05$ & 0.885 & 0.778 & 0.730 \\
\hline 21 & 1.195 & 1.050 & 0.985 & $6.08 \mathrm{E}-05$ & $9.48 \mathrm{E}-05$ & $8.85 \mathrm{E}-05$ & 1.195 & 1.050 & 0.985 \\
\hline 22 & 1.527 & 1.343 & 1.260 & $7.77 \mathrm{E}-05$ & $1.21 \mathrm{E}-04$ & $1.13 \mathrm{E}-04$ & 1.527 & 1.343 & 1.260 \\
\hline 23 & 1.475 & 1.297 & 1.217 & $7.50 \mathrm{E}-05$ & $1.17 \mathrm{E}-04$ & $1.09 \mathrm{E}-04$ & 1.475 & 1.297 & 1.217 \\
\hline 24 & 1.032 & 0.908 & 0.852 & $5.25 \mathrm{E}-05$ & $8.19 \mathrm{E}-05$ & $7.65 E-05$ & 1.032 & 0.908 & 0.852 \\
\hline 25 & 0.516 & 0.454 & 0.426 & $2.63 \mathrm{E}-05$ & $4.10 \mathrm{E}-05$ & $3.82 \mathrm{E}-05$ & 0.516 & 0.454 & 0.426 \\
\hline 26 & 1.373 & 1.207 & 1.133 & $6.98 \mathrm{E}-05$ & $1.09 \mathrm{E}-04$ & $1.02 \mathrm{E}-04$ & 1.373 & 1.207 & 1.133 \\
\hline 27 & 1.549 & 1.361 & 1.277 & $7.88 \mathrm{E}-05$ & $1.23 \mathrm{E}-04$ & $1.15 \mathrm{E}-04$ & 1.549 & 1.362 & 1.277 \\
\hline 28 & 1.667 & 1.466 & 1.375 & $8.48 \mathrm{E}-05$ & $1.32 \mathrm{E}-04$ & $1.23 \mathrm{E}-04$ & 1.667 & 1.466 & 1.375 \\
\hline 29 & 1.143 & 1.005 & 0.943 & $5.81 \mathrm{E}-05$ & $9.07 \mathrm{E}-05$ & $8.47 \mathrm{E}-05$ & 1.143 & 1.005 & 0.943 \\
\hline 30 & 1.359 & 1.195 & 1.121 & $6.91 \mathrm{E}-05$ & $1.08 \mathrm{E}-04$ & $1.01 \mathrm{E}-04$ & 1.359 & 1.195 & 1.121 \\
\hline Min & 0.074 & 0.065 & 0.061 & $3.75 \mathrm{E}-06$ & $5.85 \mathrm{E}-06$ & $5.46 \mathrm{E}-06$ & 0.074 & 0.065 & 0.061 \\
\hline Max & 1.696 & 1.491 & 1.399 & $8.63 \mathrm{E}-05$ & $1.35 \mathrm{E}-04$ & $1.26 \mathrm{E}-04$ & 1.696 & 1.491 & 1.399 \\
\hline Mean & 1.127 & 0.990 & 0.929 & $5.73 \mathrm{E}-05$ & $8.94 \mathrm{E}-05$ & $8.34 \mathrm{E}-05$ & 1.127 & 0.991 & 0.929 \\
\hline
\end{tabular}

Acknowledgments The authors are thankful to the Editor-in-Chief and anonymous reviewers for their valuable and constructive suggestions to improve the manuscript in the present form.

Funding The Science and Engineering Research Board (SERB), Department of Science and Technology (DST), Government of India (File. No: ECR/2017/000132 dated 18.07.2017) provided the funds to execute this research.

\section{Compliance with Ethical Standards}

Conflict of interest The authors declare that they have no known competing financial interests or personal relationships that could have influenced the work reported in this paper.

\section{References}

Adimalla N, Qian H (2019) Groundwater quality evaluation using water quality index (WQI) for drinking purposes and human health risk (HHR) assessment in an agricultural region of Nanganur, south India. Ecotoxicol Environ Saf 176:153-161. https://doi. org/10.1016/j.ecoenv.2019.03.066

Ahada CPS, Suthar S (2018) Assessing groundwater hydrochemistry of Malwa Punjab, India. Arab J Geosci. https://doi.org/10.1007/ s12517-017-3355-8

Amaral SL, Azevedo LB, Buzalaf MA, Fabricio MF, Fernandes MS, Valentine RA, Maguire A, Zohoori FV (2018) Effect of chronic exercise on fluoride metabolism in fluorosis-susceptible mice exposed to high fluoride. Sci Rep 8:3211 
Anand B, Karunanidhi D (2020) Long term spatial and temporal rainfall trend analysis using GIS and statistical methods in Lower Bhavani basin, Tamil Nadu, India. Indian J Mar Sci 49(03):419-427

APHA (2005) Standard methods for the examination of water and wastewater (21st ed) Washington: American Public Health Association/American Water Works Association/Water Environment Federation

Aravinthasamy P, Karunanidhi D, Subramani T, Srinivasamoorthy K, Anand B (2019) Geochemical evaluation of fluoride contamination in groundwater from Shanmuganadhi River basin, South India: implication on human health. Environ Geochem Hlth. https ://doi.org/10.1007/s10653-019-00452-x

Aravinthasamy P, Karunanidhi D, Subba Rao N, Subramani T, Srinivasamoorthy K (2020a) Irrigation risk assessment of groundwater in a non-perennial river basin of South India: implication from irrigation water quality index (IWQI) and geographical information system (GIS) approaches. Arab J Geosci. https://doi. org/10.1007/s12517-020-06103-1

Aravinthasamy P, Karunanidhi D, Subramani T, Roy PD (2020b) Demarcation of groundwater quality domains using GIS for best agricultural practices in the drought prone Shanmuganadhi River basin of South India. Environ Sci Poll Res. https://doi. org/10.1007/s11356-020-08518-5

Arya S, Subramani T, Vennila G, Karunanidhi D (2019) Health risks associated with fluoride intake from rural drinking water supply and inverse mass balance modeling to decipher hydrogeochemical processes in Vattamalaikarai River basin. Environ Geochem Health, South India. https://doi.org/10.1007/s10653-019-00489-y

Arya S, Subramani T, Vennila G, Roy PD (2020) Groundwater vulnerability to pollution in the semi-arid Vattamalaikarai River Basin of south India thorough DRASTIC index evaluation. Geochemistry 80(4):125635. https://doi.org/10.1016/j.chemer.2020.125635

Dehbandi R, Moore F, Keshavarzi B (2018) Geochemical sources, hydrogeochemical behavior, and health risk assessment of fluoride in an endemic fluorosis area, central Iran. Chemosphere 193:763-776. https://doi.org/10.1016/j.chemosphere.2017.11.021

Edmunds WM, Smedley PL (2005) Fluoride in natural waters. In: Selinus O (ed) Essentials of medical geology. Elsevier Academic Press, London, pp 301-329

Emenike CP, Tenebe IT, Jarvis P (2018) Fluoride contamination in groundwater sources in Southwestern Nigeria: assessment using multivariate statistical approach and human health risk. Ecotox Environ Saf 156:391-402

Fallahzadeh RA, Miri M, Taghavi M, Gholizadeh A, Anbarani R, Hosseini-Bandegharaei A, Ferrante M, Conti GO (2018) Spatial variation and probabilistic risk assessment of exposure to fluoride in drinking water. Food Chem Toxicol 113:314-321

Ghaderpoori M, Kamarehie B, Jafari A, Ghaderpoury A, Karami MA (2018) Heavy metals analysis and quality assessment in drinking water-Khorramabad city. Iran. Data Brief 16:658-692

GSI (1995) Geological and mineral map of Tamil Nadu and Pondicherry. Published by the Director General Geological Survey of India on 1: 500,000 Scale

Guissouma W, Hakami O, Al-Rajab AJ, Tarhouni J (2017) Risk assessment of fluoride exposure in drinking water of Tunisia. Chemosphere 177:102-108. https://doi.org/10.1016/j.chemospher e.2017.03.011

Hussin NH, Yusoff I, Wan Muhd Tahir WZ, Mohamed I, Ibrahim AIN, Rambli A (2016) Multivariate statistical analysis for identifying water quality and hydrogeochemical evolution of shallow groundwater in quaternary deposits in the Lower Kelantan River Basin, Malaysian Peninsula. Environ Earth Sci. https://doi.org/10.1007/ s12665-016-5705-3

Karunanidhi D, Aravinthasamy P, Subramani T, Wu J, Srinivasamoorthy K (2019) Potential health risk assessment for fluoride and nitrate contamination in hard rock aquifers of Shanmuganadhi River basin. South India. Hum Ecol Risk Assess 25(1-2):250270. https://doi.org/10.1080/10807039.2019.1568859

Karunanidhi D, Aravinthasamy P, Roy PD, Praveenkumar RM, Prasanth K, Selvapraveen S, Thowbeekrahman A, Subramani T, Srinivasamoorthy K (2020a) Evaluation of non-carcinogenic risks due to fluoride and nitrate contaminations in a groundwater of an urban part (Coimbatore region) of south India. Environ Monit Assess 192(2):102. https://doi.org/10.1007/s10661-019-8059-y

Karunanidhi D, Aravinthasamy P, Deepali M, Subramani T, Roy PD (2020b) The effects of geochemical processes on groundwater chemistry and the health risks associated with fluoride intake in a semi-arid region of South India. RSC Adv 10:4840. https://doi. org/10.1039/c9ra10332e

Karunanidhi D, Aravinthasamy P, Kumar D, Subramani T, Roy PD (2020c) Sobol sensitivity approach for the appraisal of geomedical health risks associated with oral intake and dermal pathways of groundwater fluoride in a semi-arid region of south India. Ecotox Environ Saf 194:110438. https://doi.org/10.1016/j.ecoen v.2020.110438

Karunanidhi D, Aravinthasamy P, Subramani T, Muthusankar G (2020d) Revealing drinking water quality issues and possible health risks based on water quality index (WQI) method in the Shanmuganadhi River basin of South India. Environ Geochem Hlth. https://doi.org/10.1007/s10653-020-00613-3

Karunanidhi D, Aravinthasamy P, Subramani T, Kumar, M (2020e) Human health risks associated with multipath exposure of groundwater nitrate and environmental friendly actions for quality improvement and sustainable management: a case study from Texvalley (Tiruppur region) of India. Chemosphere. https://doi. org/10.1016/j.chemosphere.2020.129083

Li P, He X, Li Y, Xiang G (2018) Occurrence and health implication of fluoride in groundwater of loess aquifers in the Chinese Loess Plateau: a case study of Tongchuan, northwest China. Expo Health. https://doi.org/10.1007/s12403-018-0278-x

Marghade D, Malpe DB, Zade AB (2011) Major ion chemistry of shallow groundwater of a fast-growing city of Central India. Environ Monit Assess. https://doi.org/10.1007/s1066 1-011-2126-3

Marghade D, Malpe DB, Subba Rao N (2019a) Applications of geochemical and multivariate statistical approaches for the evaluation of groundwater quality and human health risks in a semi-arid region of eastern Maharashtra, India. Environ Geochem Health. https://doi.org/10.1007/s10653-019-00478-1

Marghade D, Malpe DB, Rao NS, Sunitha B (2020) Human and ecological risk assessment: an international geochemical assessment of fluoride enriched groundwater and health implications from a part of Yavtmal district, India. Hum Ecol Risk Assess 26:673694. https://doi.org/10.1080/10807039.2018.1528862

Marghade D, Malpe DB, Subbarao N, Sunitha B (2019b) Geochemical assessment of fluoride enriched groundwater and health implications from a part of Yavtmal district, India. Hum Ecol Risk Assess. https://doi.org/10.1080/10807039.2018.1528862

Mohammadi AA, Yousefi M, Soltani J, Ahangar AG, Javan S (2018) Using the combined model of gamma test and neuro-fuzzy system for modeling and estimating lead bonds in reservoir sediments. Environ Sci Pollut Contr Series 25:30315-30324

Mukherjee I, Singh UK, Patra PK (2019) Exploring a multi-exposure-pathway approach to assess human health risk associated with groundwater fluoride exposure in the semi-arid region of east India. Chemosphere. https://doi.org/10.1016/j.chemospher e.2019.05.278

Naderi M, Jahanshahi R, Dehbandi R (2020) Two distinct mechanisms of fluoride enrichment and associated health risk in springs' water near an inactive volcano, southeast Iran. Ecotoxicol Environ Saf 195:110503. https://doi.org/10.1016/j.ecoenv.2020.110503 
Piper AM (1944) A graphic procedure in the geochemical interpretation of water-analyses. Trans Am Geophys Union 25:914-928

Priya KL, Nalini J, Prince AG (2011) Groundwater quality in the Singanallur sub-basin of Coimbatore city. J Industrial Pollut Control 27(1):15-18

Qasemi M, Shams M, Sajjadi SA, Farhang M, Erfanpoor S, Yousefi M, Zarei A, Afsharnia M (2019) Cadmium in groundwater consumed in the rural areas of Gonabad and Bajestan, Iran: occurrence and health risk assessment. Biol Trace Elem Res 192:106-115

Sarath Prasanth SV, Magesh NS, Jitheshlal KV, Chandrasekar N, Gangadhar K (2012) Evaluation of groundwater quality and its suitability for drinking and agricultural use in the coastal stretch of Alappuzha District, Kerala, India. Appl Water Sci 2(3):165-175. https://doi.org/10.1007/s13201-012-0042-5

Shen J, Schäfer AI (2015) Factors affecting fluoride and natural organic matter (NOM) removal from natural waters in Tanzania by nanofiltration/reverse osmosis. Sci Total Environ 527-528:520-529. https://doi.org/10.1016/j.scitotenv.2015.04.037

Singh AK, Giri S, Chaturvedi A (2018) Fluvial geochemistry of Subarnarekha River basin, India. J Earth Syst Sci 127:1-22. https:// doi.org/10.1007/s12040-018-1020-6

Su Z, Wu J, He X, Elumalai V (2020) Temporal changes of groundwater quality within the groundwater depression cone and prediction of confined groundwater salinity using Grey Markov model in Yinchuan area of northwest China. Expo Health. https://doi. org/10.1007/s12403-020-00355-8

Subba Rao N, Marghade D, Dinakar A, Chandana I, Sunitha B, Ravindra B, Balaji T (2017) Geochemical characteristics and controlling factors of chemical composition of groundwater in a part of Guntur district, Andhra Pradesh. India. Environ Earth Sci 76:747. https://doi.org/10.1007/s12665-017-7093-8

Subba Rao N, Sunitha B, Adimalla N, Chaudhary M (2019) Quality criteria for groundwater use from a rural part of Wanaparthy District, Telangana State, India, through ionic spatial distribution (ISD), entropy water quality index (EWQI) and principal component analysis (PCA). Environ Geochem Health. https://doi. org/10.1007/s10653-019-00393-5

Subramani T, Rajmohan N, Elango L (2009) Groundwater geochemistry and identification of hydrogeochemical processes in a hard rock region, Southern India. Environ Monit Assess 162(1-4):123137. https://doi.org/10.1007/s10661-009-0781-4

Subramani T, Babu S, Elango L (2012) Computation of groundwater resources and recharge in chithar River basin, South India. Environ Monit Assess 185(1):983-994. https://doi.org/10.1007/s1066 1-012-2608-y

Subramani T, Anandakumar S, Kannan R, Elango L (2013) Identification of major hydrogeochemical processes in a hard rock terrain by NETPATH modeling. Book on Earth Resour Environ 29:365-370
Susheela AK (2002) Fluorosis in developing countries remedial measures and approaches. Proc Indian Natl Sci Acad (PINSA) 68B(5):389-400

Thilagavathi N, Subramani T, Suresh M (2015) Land use/land cover change detection analysis in Salem chalk hills, South India using remote sensing and GIS. Disaster Adv 8:44-52

Tiwari AK, Singh AK, Mahato MK (2018) Assessment of groundwater quality of 636 Pratapgarh district in India for suitability of drinking purpose using water quality index 637 (WQI) and GIS technique. Sustain Water Res Manag 4:601-616

Udayalaxami G, Himabinda D, Ramadass G (2010) Geochemical evaluation of ground water quality in selected areas of Hyderabad, A P India. Ind J Sci Technol 3:546-553

United States Environmental Protection Agency (USEPA) (2009) National Primary Drinking Water Regulations. (https://www.epa. gov/ground-water-and-drinking-water/national-primarydrinking -water-regulations\#Microorganisms)

USEPA (United States Environmental Protection Agency) (1989) Superfund Public Health Evaluation Manual. Washington, DC

Venkatesan G, Subramani T, Sathya U, Roy PD (2020) Seasonal changes in groundwater composition in an industrial center of south India and quality evaluation for consumption and health risk using geospatial methods. Geochemistry 80(4):125651. https:// doi.org/10.1016/j.chemer.2020.125651

Walia T, Abu Fanas S, Akbar M, Eddin J, Adnan M (2017) Estimation of fluoride concentration in drinking water and common beverages in United Arab Emirates (UAE). Saudi Dent. J. 29:117-122. https ://doi.org/10.1016/j.sdentj.2017.04.002

Wang D, Wu J, Wang Y, Ji Y (2020) Finding high-quality groundwater resources to reduce the hydatidosis incidence in the Shiqu County of Sichuan Province, China: analysis, assessment, and management. Expo Health 12:307-322. https://doi.org/10.1007/ s12403-019-00314-y

WHO (2006) Fluoride in drinking water, World Health Organization. IWA Publication, London

WHO (2011) Guidelines for drinking-water quality, 4th edn. World Health Organization, Geneva

World health statistics (2017) Monitoring health for the SDGs, 2017. Sustainable Development Goals. World Health Organization, Geneva Licence: CC BY-NC-SA 3.0 IGO

Yousefi M, Ghoochani M, Mahvi AH (2018) Health risk assessment to fluoride in drinking water of rural residents living in the Poldasht city, Northwest of Iran. Ecotoxicol Environ Saf 148:426-430

Zhang L, Huang D, Yang J, Wei X, Qin J, Ou S, Zhang Z, Zou Y (2017) Probabilistic risk assessment of Chinese residents' exposure to fluoride in improved drinking water in endemic fluorosis areas. Environ Pollut 222:118-125. https://doi.org/10.1016/j.envpo 1.2016.12.074 